\title{
A Design of Nonlinear PID Control Systems Using Boosting Algorithm
}

\author{
Sho Kawanari Student Member (Kure College of Technology, s200605@st.kure-nct.ac.jp) \\ Yoshihiro Ohnishi Member (Kure College of Technology, onishi@kure-nct.ac.jp)
}

Keywords: boosting algorithm, adaboost, PID control

There are a lot of nonlinear systems in the process control systems. However, it is difficult to deal with the nonlinear property by linear controller. Also adaptive control system such as self-tuning PID control schemes is proposed, but the one made from recursive least squares can deal with only linear object. Fig. 1 draws trajectories of the system output, the system input and the reference signal on the vertical axis and the number of the steps on the horizontal axis by using self-tuning PID scheme. There are some overshoot depending on a reference signal. The controlled object of this result is Hammerstein model which has nonlinear properties.

On the other hand, a scheme called boosting is proposed in the machine learning field. This scheme can obtain the highly accurate condition by combining some less-accurate conditions. The boosting can obtain better results compared with the neural network under the less number of learning data. The original boosting is only possible to deal with two-valued variable, so we extend the algorithm for function approximation using it. Then we propose a design method of nonlinear PID control systems using extended boosting algorithm. Fig. 2 expresses the relationship between refer-

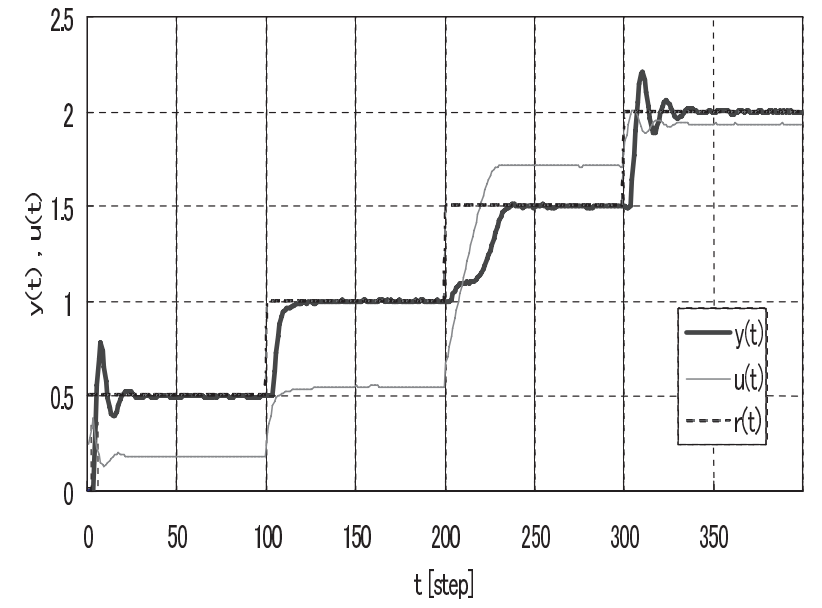

Fig. 1. Control results by using self-tuning PID scheme ence signal and design parameter of a generalized minimum variance control (GMVC), and it obtained by boosting algorithm. Fig. 3 shows control results of the same object as Fig. 1 by using GMVC with calculated design parameter.

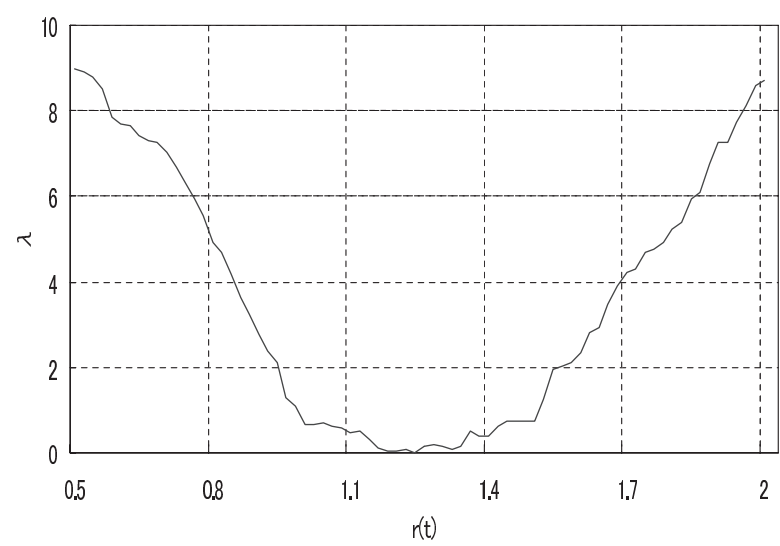

Fig. 2. Calculated result of design parameter by using booting

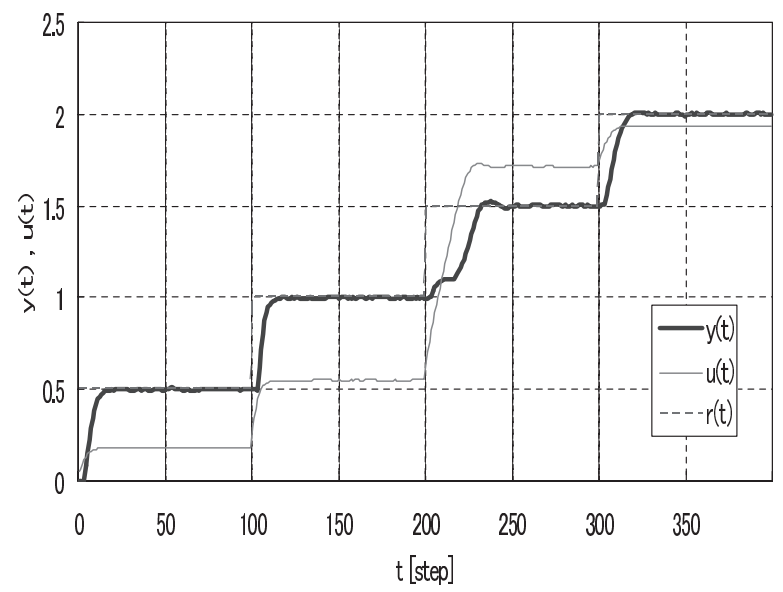

Fig. 3. Control results by using proposed control scheme 


\title{
ブースティングアルゴリズムを用いた 非線形PID 制御系の一設計
}

\author{
学生員 川成 翔* 正 員 大西 義浩*
}

\section{A Design of Nonlinear PID Control Systems Using Boosting Algorithm}

Sho Kawanari*, Student Member, Yoshihiro Ohnishi*, Member

There are a lot of nonlinear systems in the process control systems. However, it is difficult to deal with the nonlinear property by linear controller. Then, various methods have been studied in this field.

On the other hand, a scheme called boosting is proposed in the machine learning field. This scheme can obtain the highly accurate condition by combining some less-accurate conditions. The boosting can obtain better results compared with the neural network under the less number of learning data.

In this paper, we propose a design method of nonlinear PID control systems using boosting algorithm. The original boosting is only possible to deal with two-valued variable, so we extend the algorithm for function approximation using it. Finally, the simulation examjples are demonstrated in order to investigate the effectiveness of proposed scheme.

キーワード：ブースティングアルゴリズム，アダブースト，PID 制御

Keywords: boosting algorithm, adaboost, PID control

\section{1. 緒言}

制御対象に対して，理想的な制御系を設計するにあたつ て，通常はその制御対象を数式モデルであらわす必要があ る。従って，設計時には制御対象の特性が既知，つまり，制 御対象を記述する数式モデル（伝達関数や状態方程式など） およびそれに含まれるパラメータも既知でなければならな い。しかし，一般に制御対象の特性を正確に把握して数式 モデルで表現することは困難とされている。特に化学プラ ントなどに代表されるプロセス制御系は PID 制御が主と して用いられているのだが，そのほとんどが非線形特性を 有しており，数式モデルで記述できないような要素を含む ことが多い(1)。また，非線形特性をもつことにより，制御 対象の構造が多様化し, 制御器の設計が複雑となることか ら制御の性能が劣化する恐れがある。セルフチューニング $\mathrm{PID}^{(2)}$ などの適応制御も提案されているが，逐次型最小二 乗法を元にしたものなどは線形な対象にしか対応すること ができない。非線形システムに対する制御手法であるゲイ ンスケジューリング (3) は, 何度もの試行錯誤的な調整が 必要となる。そこで，この分野では古くから様々な方法が

\footnotetext{
$*$ 点工業高等専門学校

T 737-0004 広島県呉市阿賀南 2-2-11

Kure College of Technology

2-2-11, Agaminami, Kure city, Hiroshima 737-0004
}

研究されてきた ${ }^{(4)}$ 。PID 制御の分野でも，ゲインを調整 し, 線形時変システムに対処する方法 (5) や, 非線形特性に 対処する方法 ${ }^{(6)}$ が提案されており，それぞれ良好な結果が 得られている。しかしながら，これらの方法のゲインスケ ジューリングは, 予備実験や事前情報からの周波数特性解 析などを行うため, 実装に至るまでは多くの情報と何段階 もの工程を必要としている。

一方, 機械学習の分野でブースティングという方法が提 案されており, (7) (8)。パターン認識などへの応用が報告さ れている。(9)この方法はデータの数に関わらず学習条件の 数を設定できるため, 条件の決め方によって学習精度が変 わってくるという特徴を有している ${ }^{(10)}$ 。すなわち，学習 データの個数が少ない場合においても, 代表的な知的情報 処理手法であるニューラルネットワークなどに比べて良好 な学習結果が得られる可能性があると考えられている。

本論文ではブースティングアルゴリズムを用いた非線形 制御系設計を提案する。今回用いるブースティングの中で も代表的なアダブーストというアルゴリズムは, 本来, 単 純な 2 值判別問題しか取り扱うことができない。よって，ま ずアダブーストを用いた関数近似法を考察する。それから， その関数近似を用いて導出した設計パラメータを使用する ことにより，非線形性に対応する制御系を実現する。最後 に，本手法を非線形モデルの一つである Hammerstein モ デルに適用し，その有効性を示す。 


\section{2. ブースティングを用いた関数近似}

$\langle\mathbf{2} \cdot \mathbf{1}\rangle$ ブースティングの使用目的通常の線形制御法 では制御入力に対する重み係数は固定されており，非線形 な制御対象の特性変動に対応できない可能性があった。そ こで，今回はブースティングを用いた関数近似により，そ のパラメータを導出する方法を提案する。以下ではブース ティングについての概略と，それを用いたパラメータの導 出法について記述する。

〈2·2〉 アダブーストの概略＼cjkstart本論文では，ブースティ ングに関する最近の研究成果の中から，特にこれまで多く の理論的な検証と実験的実証がなされてきたアダブースト を取り上げる。アダブーストは 2 值判別問題の算法であり, 現実に適用するにあたって多くの優れた性質を持っている。 例えば，極めて単純でプログラムも簡単であり，計算も効 率的である。ラウンド数 $T$ を別にすれば調整の必要なパラ メー夕もない。理論的な性能保証も与えられており, 過学 習にも強いとされている。しかしながら, 学習デー夕に外 れ值を含む場合は，学習結果が不安定になる恐机も指摘さ れている。本論文においては, 関数近似に応用する際に学 習データを自己生成しノイズの影響がないため，このよう な問題を回避することができる。

$\langle\mathbf{2} \cdot \mathbf{3}\rangle \quad$ アダブーストアルゴリズム 2 值判別問題のア ルゴリズムは以下のようになる。詳細は，文献 (7) および (8)を参照されたい。

（1）入力として，用意された $N$ 個の学習デー夕 $\left\{\left(x_{1}, y_{1}\right), \ldots,\left(x_{N}, y_{N}\right)\right\}$ を受け取る。ただし,$x_{i} \in$ $X, y_{i} \in Y=\{-1,+1\}$ とする。

(2) 初期の事例の重みを $D_{1}(i)=1 / N$ によって初期 化する。

(3) $t=1, \ldots, T$ に対して,

- 確率分布 $D_{t}$ に基づいて誤り率 $\epsilon_{t}$ を次式に従っ て計算し， $\epsilon_{t}$ が最小となる弱仮説 $h_{t}$ を選ぶ。

$$
\begin{aligned}
\epsilon_{t} & =\operatorname{Pr}_{D_{t}}\left\{h_{t}\left(x_{i}\right) \neq y_{i}\right\} \\
& =\sum_{h_{t} \text { が間違えた } i} D_{t}(i) .
\end{aligned}
$$

・選ばれた仮説の誤り率を用いて, 弱仮説の信頼 度 $\alpha_{t}$ を次式に従って計算する。

$$
\alpha_{t}=\frac{1}{2} \ln \left(\frac{1-\epsilon_{t}}{\epsilon_{t}}\right)
$$

・確率分布 $D_{t}$ を更新する。

$$
D_{t+1}(i)=\frac{D_{t}(i) \exp \left(-\alpha_{t} y_{i} h_{t}\left(x_{i}\right)\right)}{\sum_{i=1}^{N} D_{t}(i) \exp \left(-\alpha_{t} y_{i} h_{t}\left(x_{i}\right)\right)}
$$

（4） 入力 $x$ に対する最終仮説 $H(x)$ は

$$
H(x)=\operatorname{sign}\left(\sum_{t=1}^{T} \alpha_{t} h_{t}(x)\right) .
$$

によって得られ，H(x)の符号により 2 值判別が可 能となる。
つまり，最終仮説は各弱仮説の信頼度による重み付け多 数決となる。

〈2・4〉 関数近似への応用上記したアダブーストのア ルゴリズムでは，単純な 2 值判別問題しか取り扱うことが できない。本論文では，非線形関数の近似を行うため，関 数近似問題への応用を考察する ${ }^{(10)}$ 。

まず， 2 值判別問題への帰着を行う。アダブースト自体で 扱える值，具体的には学習デー夕の $y_{i}$ 抢よび弱仮説による 予想 $h_{t}\left(x_{i}\right)$ は本来の 2 值しか許されていない。そこで, 対 象とする関数により適当な閾値を設定し, その值を基準に真 と偽の 2 值に分ける。たとえば，正弦波関数 $y(t)=\sin 10 x$ （ただし， $0<x \leq 1)$ の近似を行う場合，閥值を 0 とする と, 正の值をとっている点を+, 負の值をとっている点を一 と打く。

次に，弱仮説を設定する。上記の正弦波関数の場合，任 意の $x 1<x<x 2$ という範囲を設定し, この範囲内であ れば十であるという仮説を立てることを意味している。こ の範囲内にある学習デー夕から, その弱仮説の信頼度を計 算する。もし，この範囲内に学習デー夕が 3 つあり， 2 つ が十であると，この弱仮説の信頼度は 0.667 である。

しかしながら，本来のアダブーストは $H(x)$ の符号によ り判断するので, 出力は+か一か (真か偽か) の二值に限 られる。このままでは関数の近似には用いることができな いので，信頼度の総和である $H(x)$ の值そのものを利用す ることとする。つまり, 近似範囲を複数個に分割し入力 $x$ として計算し, 得られた $H(x)$ の值を正規化し, その值を 直線で結んだ関数が対象関数の近似関数となる。

$\langle\mathbf{2} \cdot \mathbf{5}\rangle$ 弱仮説の自動生成法より正確な近似結果を 得るためには弱仮説の数を増やすことが必要であるが，手 動で決める数には限度がある。そこで, 適当な数列を用い て $x 1, x 2$ を設定し

$$
\begin{aligned}
& x \geq x 1 \cap x \leq x 2 \text { の時 } \Rightarrow h_{t}\left(x_{i}\right)=+1 \ldots \ldots \ldots \\
& \text { それ以外 } \Rightarrow h_{t}\left(x_{i}\right)=-1 \ldots \ldots \ldots \ldots \ldots \ldots
\end{aligned}
$$

という条件の弱仮説を自動的に作成する。これが，弱仮説 である条件 $\epsilon_{t} \leq 1 / 2$ を満たしている場合はその時点で採 用し，満たしていない場合は新たな弱仮説を再度作成する。 ただ $, x 1, x 2$ は任意の数值であり, その值の範囲は近 似関数の範囲により適当に設定する。

\section{3. 制御系の設計}

〈3・1 システムの記述 制御対象として次式で表せ れる非線形離散時間システムを考える。

$$
y(t)=G(\mathbf{u}, \mathbf{y})
$$

ただし， $\mathbf{u}$ および $\mathbf{y}$ は制御入力ベクトルおよびそれに対応 したシステム出力ベクトルを表しており，次式で与えられ るものとする。

$$
\mathbf{u}=[u(t-k-1), u(t-k-2), \ldots, u(t-k-m)]
$$




$$
\mathbf{y}=[y(t-1), u(t-2), \ldots, u(t-n)]
$$

さらに，Gは非線形関数を意味しており， $k$ はむだ時間を表 している。ここで，(7) 式で表される制御対象のシステム同 定を行うことを考えた場合，その構造が既知であれば，直 接的に同定を行うのが容易な場合もある。しかし未知の場 合では困難となってしまう。また，複雑な数式モデルを用 いてモデリングを行うことは，制御系設計を考える上で好 ましくない場合もある。そこで，本論文では対象とする非 線形システムを次式のような線形の同定モデルで記述する。

$$
A\left(z^{-1}\right) y(t)=z^{-k_{m}} B\left(z^{-1}\right) u(t-1)+X\left(z^{-1}\right) \xi(t)
$$

ただし， $A\left(z^{-1}\right)$ および $B\left(z^{-1}\right)$ は次式で与えられる多項式 であり，本論文では既知とする。

$$
\begin{aligned}
& A\left(z^{-1}\right)=1+a_{1} z^{-1}+a_{2} z^{-2} \\
& B\left(z^{-1}\right)=b_{0}+b_{1} z^{-1}+\ldots+b_{m} z^{-m} \ldots \ldots
\end{aligned}
$$

さらに， $X\left(z^{-1}\right)$ は次式の雑音モデルであり,こちらも既 知であるものとする。

$$
X\left(z^{-1}\right)=1+x_{1} z^{-1}+\ldots x_{n} z^{-n} .
$$

ここで， $z^{-1}$ は時間遅れ作用素である。 $u(t)$ および $y(t)$ は それぞれ，制御入力とシステム出力を示しており， $\xi(t)$ は 観測ノイズなどを含む確率雑音であり，さらに， $k_{m}$ はむ だ時間の最小推定值を示している。つまり，むだ時間が既 知の場合は $k_{m}$ はその值を設定し，未知ではあるが 3-5 ス テップくらいの間にあるなど，ある程度予想できる場合は $k_{m}=3$ と設定する。また，むだ時間が存在する範囲が全く 把握できない場合は $k_{m}=0$ と設定する。このように，む だ時間のパラメータを分子多項式に吸収させることにより， 未知むだ時間系を扱うことが可能となる。なお，一般にシ ステムは $n$ 次の記述モデルで表せられることが多いが，プ ロセス制御系ではそのほとんどが 2 次系以下で記述される ことが多いことを考慮して，ここでは (11) 式および (12) 式を記述モデルとして用いる。また， $\{\xi(t)\}$ は以下の仮定 を満足するガウス性白色雑音系列とする。

\section{〔仮定 1〕}

$$
\begin{aligned}
& \varepsilon[\xi(t)]=0 \ldots \ldots \ldots \ldots \ldots \ldots \ldots \ldots \ldots \ldots \ldots \ldots \\
& \varepsilon\left[\xi^{2}(t)\right]=\sigma_{\xi}^{2} \ldots \ldots \ldots \ldots \ldots \ldots \\
& \varepsilon[\xi(t) \xi(t+\tau)]=0 \quad(\tau \neq 0)
\end{aligned}
$$

ここで， $\varepsilon$ は期待值 (空間平均) を示している。

〈3・2〉 非線形システムに対する PID 制御今回は制 御系設計の一例として，一般化最小分散制御に基づく PID 制御を用いる方法をとった。ただし，本来これだけでは線 形な制御対象にしか対応することができない。そこで，前 章に記述したブースティングを用いて非線形システムにも 対応させる方法を最終節に示す。

〈3·3〉 PID 制御則 プロセス制御系においては, 古
くから PID 制御が用いられている。しかし，近年のディジ タル計算機の発達により, 計算が容易に行えるようになっ たことや論理的な判断が取り入れしやすくなったことから， 次式のようなディジタル PID 制御則が多く採用されるよう になってきた。

$$
\Delta u(t)=k_{c}\left(\Delta+\frac{T_{s}}{T_{I}}+\frac{T_{D}}{T_{s}} \Delta^{2}\right) e(t)
$$

ただし， $e(t)$ は制御誤差信号で，次式のように定義される。

$$
e(t):=r(t)-y(t)
$$

$r(t)$ は目標值であり，ステップ関数で与えられる。また, $k_{c}$, $T_{I}$ および $T_{D}$ はそれぞれ比例ゲイン, 積分時間, 微分時間 を示しており， $T_{s}$ はサンプリング時間を示している。

$\langle 3 \cdot 4\rangle$ 一般化最小分散制御則一般化最小分散制御 則は，次式の評価規範の最小化に基づいて導出される。

$$
J=\varepsilon\left[\phi^{2}\left(t+k_{m}+1\right)\right]
$$

$\phi\left(t+k_{m}+1\right)$ は一般化出力であり, 次式として定義される。

$$
\begin{aligned}
\phi\left(t+k_{m}+1\right): & =P\left(z^{-1}\right) y\left(t+k_{m}+1\right) \\
& +\lambda \Delta u(t)-R\left(z^{-1}\right) r(t) .
\end{aligned}
$$

ここで，入は制御入力に対する重み係数で設計パラメータ である。また, $P\left(z^{-1}\right)$ は次式により与えられる設計多項 式である。

$$
P\left(z^{-1}\right)=1+p_{1} z^{-1}+p_{2} z^{-2}+\ldots+p_{n_{p}} z^{-n_{p}}
$$

また， $R\left(z^{-1}\right)$ は後で考察する PID 制御則との関連に基づ いて決定される多項式である。(18) 式の最小化に基づく制 御則は, 次式を満足する $u(t)$ として与えられる。

$$
\begin{array}{r}
F\left(z^{-1}\right) y(t)+\left\{E\left(z^{-1}\right) B\left(z^{-1}\right)+\lambda\right\} \Delta u(t) \\
-R\left(z^{-1}\right) r(t)=0 \cdots
\end{array}
$$

ここで, $E\left(z^{-1}\right)$ および $F\left(z^{-1}\right)$ は, 次式の Diophantene 方程式に基づいて計算される。

$$
P\left(z^{-1}\right)=A\left(z^{-1}\right) E\left(z^{-1}\right)+z^{-(k m+1)} F\left(z^{-1}\right)
$$

ただし， $E\left(z^{-1}\right)$ および $F\left(z^{-1}\right)$ は次式で与えられる多項 式である。

$$
\begin{aligned}
& E\left(z^{-1}\right)=1+e_{1} z^{-1}+\ldots+e_{k_{m}} z^{-k_{m}} \ldots \ldots \\
& F\left(z^{-1}\right)=f_{0}+f_{1} z^{-1}+f_{2} z^{-2} \ldots \ldots \ldots \ldots
\end{aligned}
$$

これらの多項式の次数は，一意に計算されるようにそれぞ れ $k_{m}$ 次と 2 次となっている。 
〈3・5〉 PID パラメータの決定法 まず，(16) 式を次 式として書き換える。

$$
C\left(z^{-1}\right) y(t)+\Delta u(t)-C\left(z^{-1}\right) r(t)=0 \cdots \cdots
$$

ただし， $C\left(z^{-1}\right)$ は次式とする。

$$
\begin{aligned}
C\left(z^{-1}\right)= & c_{0}+c_{1} z^{-1}+c_{2} z^{-2} \\
= & k_{c}\left(1+\frac{T_{s}}{T_{I}}+\frac{T_{D}}{T_{s}}\right) \\
& -k_{c}\left(1+\frac{2 T_{D}}{T_{s}}\right) z^{-1}+\frac{k_{c} T_{D}}{T_{s}} z^{-2} \ldots
\end{aligned}
$$

つぎに，(18) 式の評価規範を厳密には最小化しないが，一 般化最小分散制御則 $(21)$ 式の $E\left(z^{-1}\right) B\left(z^{-1}\right)$ を定常ゲイ ン $E(1) B(1)$ に置き換えた次式を考える。ただし，(21) 式 の $E\left(z^{-1}\right)$ はむだ時間補償の働きがあるため，大きなむだ 時間をもつシステムに対してこの置き換えを行う場合は注 意が必要である。

$$
\begin{aligned}
& F\left(z^{-1}\right) y(t)+\{E(1) B(1)+\lambda\} \Delta u(t) \\
& \quad-R\left(z^{-1}\right) r(t)=0 \ldots \ldots \ldots \ldots \ldots \ldots
\end{aligned}
$$

いま， $\nu$ を次式として定義する。

$$
\nu:=E(1) B(1)+\lambda
$$

すると（27) 式は次式として書き換えることができる。

$$
\frac{F\left(z^{-1}\right)}{\nu} y(t)+\Delta u(t)-\frac{R\left(z^{-1}\right)}{\nu} r(t)=0 \cdots
$$

したがって，(25) 式と (29) 式を比較すると，

$$
\begin{aligned}
& R\left(z^{-1}\right)=F\left(z^{-1}\right) \\
& C\left(z^{-1}\right)=\frac{F\left(z^{-1}\right)}{\nu} .
\end{aligned}
$$

として $R\left(z^{-1}\right)$ および $C\left(z^{-1}\right)$ を設計すれば，一般化最小 分散制御則に基づいて PID パラメータを計算することがで きる。すなわち，(26) 式と (31) 式から, PID パラメータ は次式により計算される。

$$
\begin{aligned}
& k_{c}=-\frac{1}{\nu}\left(f_{1}+2 f_{2}\right) \cdots \\
& T_{I}=-\frac{f_{1}+2 f_{2}}{f_{0}+f_{1}+f_{2}} T_{s} \\
& T_{D}=-\frac{f_{2}}{f_{1}+2 f_{2}} T_{s} \cdots
\end{aligned}
$$

〈3・6〉 ブースティングによる PID 制御パラメータの算 出 (32) (34) 式によって PID パラメータを計算する ことができる。しかしながら，これらは (10)〜 (12) 式の線 形モデルに基ついいて計算されるため, 非線形特性に対応す ることはできない。そこで，本節では PID 制御の設計パ ラメータである入を，前章で述べたブースティングによる 関数近似により求める。求めた設計パラメータ入を目標值 ごとに設定することにより，非線形システムに対する制御 も良好に行うことが可能となる。その過程は以下の通りで ある。
(1) 適当な設計パラメータ $\lambda$ と目標值 $r(t)$ を設定し, 出力特性を見る。

(2) 得られた結果を元に, 目標值 $r(t)$ ごとに設計パラ メータ入を上げるべきか下げるべきかを決定する。

（3） $x_{i}$ を各目標值， $y_{i}$ をそれぞれの判断結果（ $\lambda$ を上

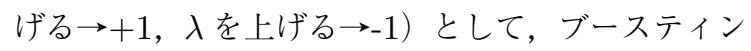
グにより, 目標值 $r(t)$ に対する設計パラメータ $\lambda$ の 関数を近似的に求める。

(4) 求めた近似関数により, 目標值 $r(t)$ に適した設計 パラメータ $\lambda$ を設定し制御を行う。

\section{4. 数 值 例}

ここでは, 提案法の有効性を検討するために行った数值 例を示す。制御対象は次式で示される Hammerstein モデ ルを用いた。

$$
\begin{aligned}
y(t)= & 0.6 y(t-1)-0.1 y(t-2) \\
& +1.2 x(t-1)-0.1 x(t-2)+\xi(t) \cdots \\
x(t)= & 1.5 u(t)-1.5 u^{2}(t)+0.5 u^{3}(t) \cdots \cdots
\end{aligned}
$$

ただし， $\xi(t)$ は平均 0 , 分散 0.01 の白色雑音である。

上式の静特性を Fig.1 に示す。Fig.1 より，このシステム は $u=1.0$ 付近に非線形性を有していることがわかる。

まず，比較実験として山本，兼田らによる設計法を用いた 制御 (2) を行う。このとき, 各パラメータはそれぞれ $\lambda=5.0$, $\lambda_{1}=1.0, \Gamma(0)=10.0$ とし, 目標值 $r(t)$ を 100 ステップ ごとに $0.5,1.0,1.5,2.0$ と変化させた。その結果を Fig. 2 に示す。

Fig. 2 から，上記のセルフチューニング PID を用いた 場合には目標值によっては大きなオーバーシュートが出て しまい，好ましくない結果となっている。これは，線形の システム同定に基づいているため, 非線形特性に対応でき ないことに起因している。

次に, 提案手法の数值例を示す。線形モデルの作成には 次式を用いた。ただし， $u=2.0$ 付近で最適となるように 作成した。

$$
\begin{aligned}
y(t)= & 0.6 y(t-1)-0.1 y(t-2) \\
& +1.2 u(t-1)-0.1 u(t-2)
\end{aligned}
$$

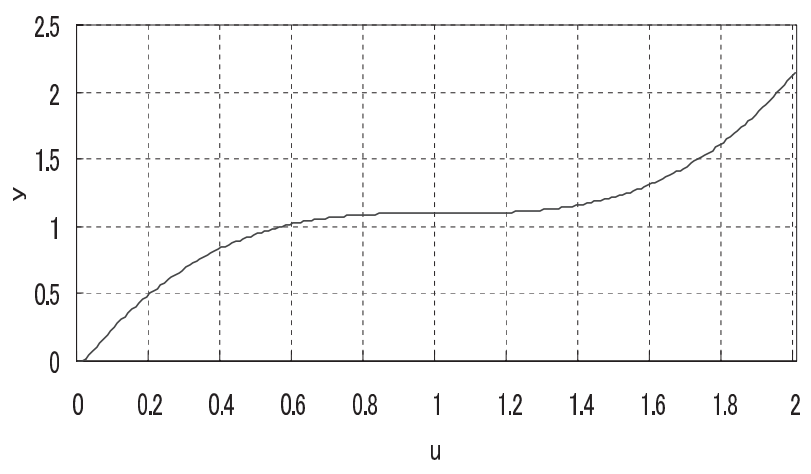

Fig. 1. Static property of controlled object. 


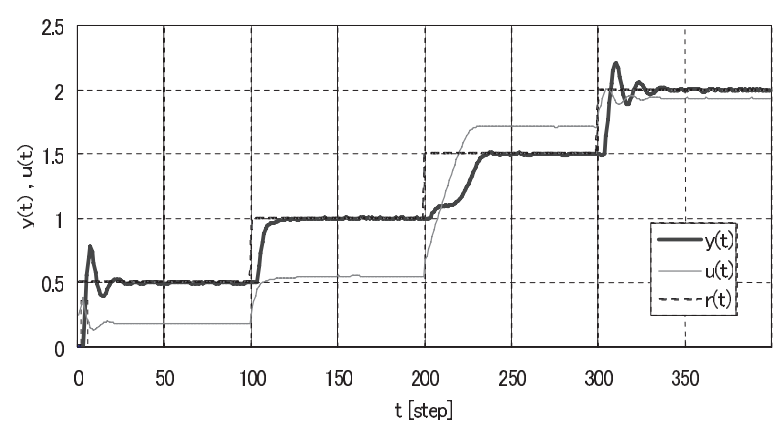

Fig. 2. Control results by using self-tuning PID scheme.

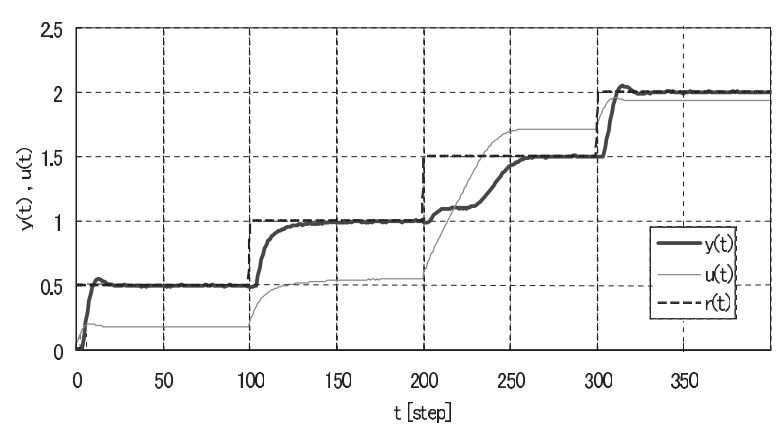

Fig. 3. Control results by using fixed design parameter.

Table 1. Training data for boosting.

\begin{tabular}{c|c|c}
\hline$i$ & $x_{i}$ & $y_{i}$ \\
\hline \hline 1 & 0.5 & -1 \\
\hline 2 & 1.0 & +1 \\
\hline 3 & 1.5 & +1 \\
\hline 4 & 2.0 & -1 \\
\hline
\end{tabular}

そして, 適当な $\lambda$ と目標值 $r(t)$ を設定し, 一般化最小分 散制御則に基づく PID 制御の出力特性を見る。 $\lambda=5.0$, 目標值を 100 ステップごとに $0.5,1.0,1.5,2.0$ と変化さ せた場合の出力特性は Fig. 3 のようになった。

Fig. 3 を見て $\lambda$ の值を上げるか下げるかを判断するのだ が，ここではオーバーシュートがなく，かつ立ち上がりの早 い制御が良いという条件にする。 $\lambda$ を大きくすると $k_{c}$ が小

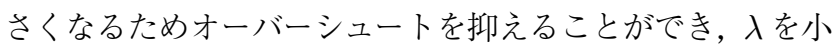
さくすると $k_{c}$ が大きくなるため立ち上がりを早めることが できる。つまり,オーバーシュートが起きている $r(t)=0.5$, $r(t)=2.0$ では $\lambda$ の值を下げてやり, $r(t)=1.0, r(t)=1.5$ では $\lambda$ の值を上げることとした。以上 4 つの地点において $\lambda$ を現在の值より上げるか下げるかという情報を元に，ブー スティングを用いた関数近似により最適な $\lambda$ を算出する。 つまり, Table 1 に示したような值を学習データとして与 え, $r(t)$ に対する $\lambda$ の関係を近似的に求めるのである。こ の時, $\lambda$ の変化はあらかじめ推測し $0.0 \sim 9.0$ の範囲とした。 その結果を Fig. 4 に示す。

Fig. 4 を見ると設計パラメータ $\lambda$ は目標值 $r(t)$ に対し て非線形な変化となっていることがわかる。この非線形性

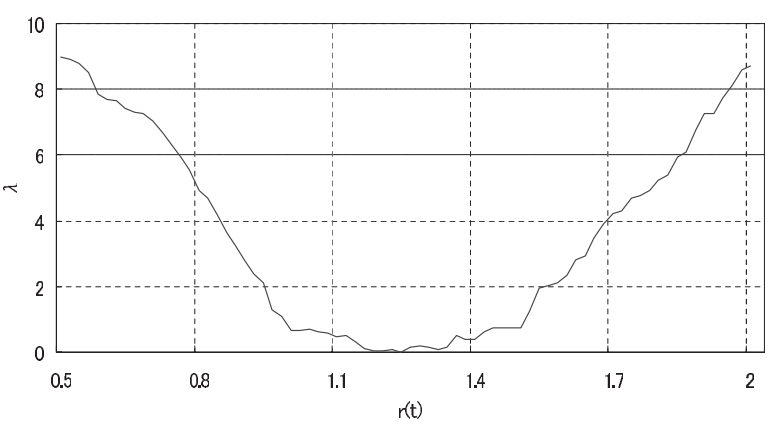

Fig. 4. Calculated result of design parameter by using booting.

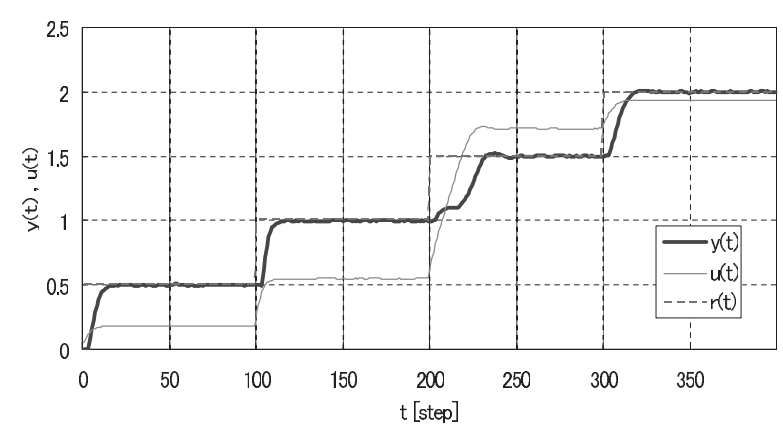

Fig. 5. Control results by using proposed control scheme.

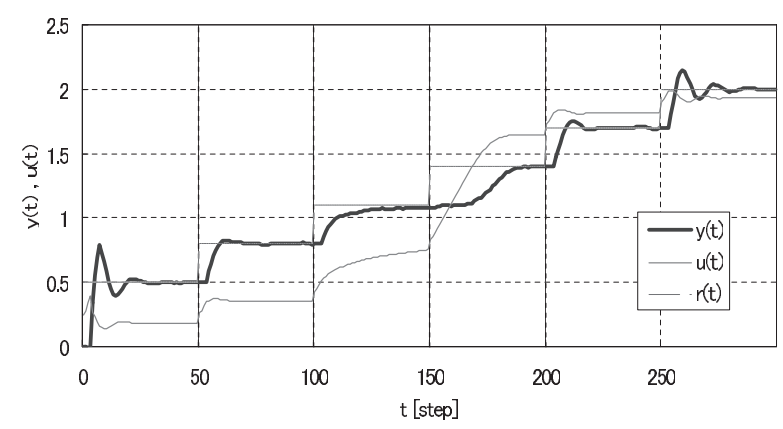

Fig. 6. Control results of other target values by using self-tuning PID scheme.

が制御対象の非線形性を打ち消し，良好な制御を可能とす

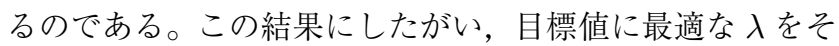
れぞれ定めた結果，Fig. 5 のようになった。

Fig. 3, Fig. 5 より, 提案手法を用いた場合は $\lambda$ を固定 した時に比べ，オーバーシュートを抑えながら目標值への 到達を早めることが可能となっていることが分かる。

学習デー夕にない目標值に対しての有効性を検証するた めに，目標值を 50 ステップごとに $0.5,0.8,1.1,1.4,1.7$, 2.0 と変化させた場合のセルフチューニング PID 制御, $\lambda$ を固定した時, 提案手法の各出力特性を順に示すと, Fig. 6, Fig. 7, Fig. 8 のようになる。

Fig. 6, Fig. 7, Fig. 8 より, 学習デー夕にない目標值 においても提案法を用いた場合の立ち上がりまでの時間は セルフチューニング PID 制御を用いた時と同程度に早くな り,オーバーシュートは通常の一般化最小分散制御に基づ 


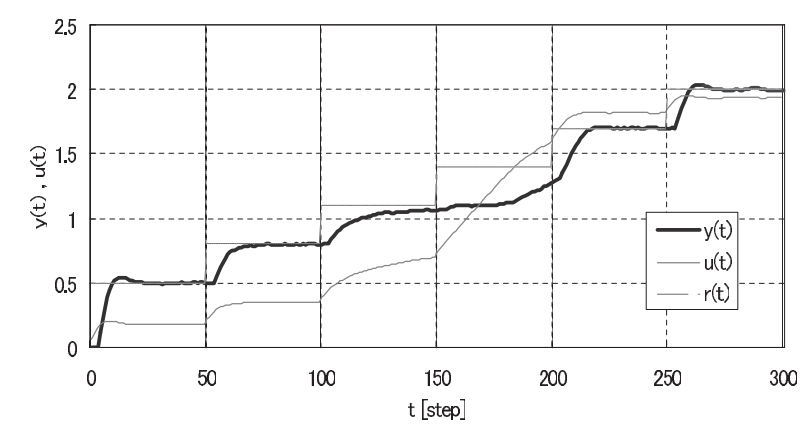

Fig. 7. Control results of other target values by using fixed design parameter.

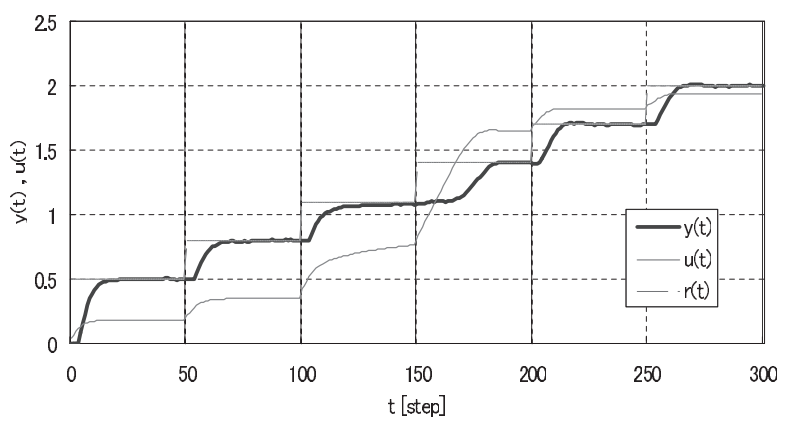

Fig. 8. Control results of other target values by using proposed control scheme.

くPID 制御を用いた時よりも少なくなっていることが分 かる。

以上により，ブースティングを用いた非線形 PID 制御の 有効性が検証された。

\section{5. 結 言}

本論文では，ブースティングを用いた非線形制御系設計 について考察した。

本手法の概要をまとめると，まず，制御系設計の一例と して制御対象に対し一般化最小分散制御則に基づく PID 制 御を適用した。そして，非線形システムにも対応できるよ う，その設計パラメータをブースティングを用いた関数近 似により導出し，最後に数值例を示した。その結果，学習 データにない目標值においても良好な制御シミュレーショ ンが行えることが分かり，本手法の有効性が検証できた。

実際にプロセス工程の制御系を設計するとなると，その システムがどのような特性を有しているかが問題となる。 本研究では第 4 章のシミュレーションによって, 数少ない 学習データから，与えられていないデータに対しても良好 な制御が行えることが示せた。プロセス系においては入出 力観測データやシステムの動的特性などの事前情報を多く 得られることもあるが，少ないデー夕のみしか得られない 場合も多々ある。したがって，本手法のような数少ないデー 夕を有効に活用した制御系設計は実用化の観点からも有効 であると考えられる。

最後に，本論文で提案したアルゴリズムは 1 つのパラメー
夕しか抽出できず，適用できる非線形システムに制限があ る。より多くのシステムに対応するため, 非線形特性に応 じて 2 つないし 3 つのパラメータを抽出できるブースティ ングアルゴリズムの開発について考察を重ねる予定である。 (平成 20 年 1 月 15 日受付, 平成 20 年 8 月 13 日再受付)

\section{文献}

（1）橋本：「技術シリーズ 13 プロセス制御 制御対象と制御方式」，化学 工学, Vol.65, No.12 pp.661-664 (2001)

(2) T. Yamamoto and M. Kaneda: "A design of self-tuning PID controllers based on the generalized minimum variance control law", Trans. on the ISCIE, Vol.11, No.1 pp.1-9 (1998) (in Japanese)

山本・兼田：「一般化最小分散制御則に基づくセルフチューニング PID 制御器の一設計」，システム制御情報学会論文誌，Vol.11, No.1 pp.1-9 (1998)

(3) K. Uchida and R. Watanabe: "Gain Scheduling : Development toward Adaptive/Nonlinear Control", Systems, control and information, Vol.42, No.6 pp.306-311 (1998) (in Japanese)

内田・渡辺：「ゲインスケジューリング：適応/非線形制御への展開」, システム制御情報学会誌, Vol.42, No.6 pp.306-311 (1998)

（4）平田・藤田・大西・山本:「局所モデル同定を用いた非線形 PID 制御 系の一設計」, 計測自動制御学会中国支部学術講演会論文集, Vol.12 pp. 202-203 (2003)

(5) R. Namba, T. Yamamoto, and M. Kaneda: "A design scheme of discrete robust PID control systems and its application" T. IEEJ, Vol.118-C, No.3, pp.320-325 (1998) (in Japanese) 難波・山本・兼田：離散時間ロバスト PID 制御法の設計法とその 応用，電学論 C, 118, 3, pp.320-325 (1998)

(6) M. Berndtsson and A. Johansson: Design of a dynamic threshold generator for $\lambda$-tuned control loops, Control Engineering Practice, Vol.16, No.5, pp.623-631 (2008)

（7） Y. Freund and R. Schapire 安倍訳：「ブースティング入門」, 人 工知能学会誌, Vol.14, No.5 pp.771-780 (1999)

（8）金森・烟埜・渡辺：「ブースティング一学習アルゴリズムの設計技 法一」, 森北出版 (2006)

(9) H. Itani and T. Furuhashi, "A Study on Action Rule Acquisition Using Boosting Algorithm", Trans. on SICE, Vol.43, No.10 pp.919-925 (2007) (in Japanese) 井谷・古橋:「ブースティングアルゴリズムを用いた自立移動ロボッ トの制御ルール獲得」, 計測自動制御学会論文集, Vol.43, No.10 pp.919-925 (2007)

（10）川成 翔・大西義浩:「ブースティングアルゴリズムを用いた関数 近似法」, 平成 19 年度電気学会全国大会講演論文集, 第 3 分冊, 3-076 pp.118 (2007)

川成 翔 (学生員) 1985 年生。 2008 年 3 月吳工業高等専

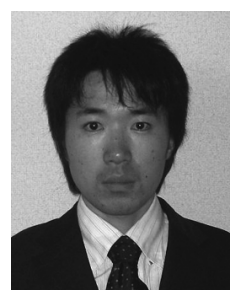
門学校専攻科機械電気工学専攻修了。同年 4 月早 稲田大学大学院情報生産システム研究科修士課程 進学，現在に至る。知的制御の研究に興味をもつ。

大 西 義 浩 （正員） 1974 年生。99 年岡山県立大学大学院情

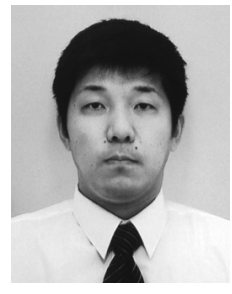
報系工学研究科修士課程修了。同年 4 月吳工業高 等専門学校電気工学科助手, 2004 年 7 月同電気 情報工学科講師となり, 現在に至る。2002 年大 阪府立大学大学院工学研究科博士課程修了。博士 (工学)。2005 年 3 月 2006 年 3 月カナダ・アル バー夕大学客員研究員。適応学習制御に関する研 究に興味をもつ。IEEE などの会員。 